Article

\title{
A Laboratory Assessment of Factors That Affect Bacterial Adhesion to Contact Lenses
}

\section{Debarun Dutta $^{1,2, *}$ and Mark DP Willcox ${ }^{1}$}

1 School of Optometry and Vision Science, The University of New South Wales, Sydney NSW 2052, Australia

2 Brien Holden Vision Institute, Sydney NSW 2052, Australia; E-Mail: m.willcox@unsw.edu.au

* Author to whom correspondence should be addressed; E-Mail: debarun.dutta@unsw.edu.au; Tel.: +612-9385-7546; Fax: +612-9385-7401.

Received: 18 July 2013; in revised form: 1 October 2013 / Accepted: 29 October 2013 /

Published: 1 November 2013

\begin{abstract}
Adhesion of pathogenic microbes, particularly bacteria, to contact lenses is implicated in contact lens related microbial adverse events. Various in vitro conditions such as type of bacteria, the size of initial inoculum, contact lens material, nutritional content of media, and incubation period can influence bacterial adhesion to contact lenses and the current study investigated the effect of these conditions on bacterial adhesion to contact lenses. There was no significant difference in numbers of bacteria that adhered to hydrogel etafilcon A or silicone hydrogel senofilcon A contact lenses. Pseudomonas aeruginosa adhered in higher numbers compared to Staphylococcus aureus. Within a genera/species, adhesion of different bacterial strains did not differ appreciably. The size of initial inoculum, nutritional content of media, and incubation period played significant roles in bacterial adhesion to lenses. A set of in vitro assay conditions to help standardize adhesion between studies have been recommended.
\end{abstract}

Keywords: Bacterial adhesion; contact lens; Pseudomonas aeruginosa; Staphylococcus aureus 


\section{Introduction}

Contact lenses provide several benefits over spectacles, but their wear has remained as a risk factor for the development of various adverse events, such as microbial keratitis (MK) [1], contact lens related acute red eye (CLARE) [2], contact lens peripheral ulcer (CLPU) [3] and infiltrative keratitis (IK) [4]. Adhesion and colonization by variety of microbes, particularly bacteria [1], to contact lenses is implicated as a major factor in the initiation of these adverse events. Pseudomonas aeruginosa and Staphylococcus aureus are the two predominant microorganisms implicated in contact lens related microbial adverse events [1,5] and other microorganisms such as Serratia marcescens [2], coagulase-negative staphylococci [1], fungus [6] and Acanthamoeba [7] are less frequently involved. Depending on the study design and location, P. aeruginosa and $S$. aureus together account $44 \%$ to $57 \%$ of total culture positive contact lens related microbial keratitis [1,8].

Bacterial adhesion to contact lenses is a complex and multifactorial process and previous in vitro and ex vivo adhesion data differ widely between various studies [9]. This is mainly due to variety of methodology used to evaluate bacterial adhesion and there are a range of assay conditions that have been used to evaluate bacterial adhesion to lenses. These conditions have included different strains/types of bacteria, contact lenses types, inoculum sizes, the nutritional content of media and the incubation time for adhesion to occur [9]. Viable plate count [10-12], number of cells adherent to parallel plate flow chambers [13], scanning electron microscopy [14], bioluminescent ATP assay [15], light microscopy [16], and assessment of the number of cells after radio-labeling [17] have been used to quantify microbial adhesion to lenses. Various solutions are used during adhesion experiments which include phosphate buffer saline (PBS) [18,19], which is nutritionally inert, and broths such as Tryptone Soy [20] or Mueller Hinton which are nutritionally rich. The reported inoculum sizes in bacterial adhesion assays have varied from $1 \times 10^{3}$ colony forming units (CFU) $\mathrm{mL}^{-1}$ up to $1 \times 10^{9} \mathrm{CFU} \mathrm{mL} \mathrm{m}^{-1}[10,21]$ and the incubation period for adhesion has ranged from 10 minutes to 72 hours [16,22].

The wide variety of bacterial assays used in previous studies and consequent differences in bacterial numbers adhering to lenses, signify a need to develop a set of standardized in vitro assay that can allow comparisons within and between studies on adhesion of different bacterial strains to different contact lenses. This study aimed for a better understanding of these major influencing factors that affect bacterial attachment and furthermore suggest key standard assay conditions that are best suited for laboratory assessment. As biofilm formation on contact lenses during wear is infrequent [23] the primary focus of this investigation was on initial steps in bacterial adhesion.

\section{Experimental Section}

Two of the most widely used contact lens materials, the hydrogel etafilcon A (ACUVUE® 2; Johnson \& Johnson Vision Care Inc., Jacksonville, FL; Base curve: $8.7 \mathrm{~mm}$, Diameter: $14.0 \mathrm{~mm}$, Power: -3.00 Diopter) and the silicone hydrogel senofilcon A (ACUVUE® OASYS ${ }^{\mathrm{TM}}$; Johnson \& Johnson Vision Care; Base curve: $8.4 \mathrm{~mm}$, Diameter: $14 \mathrm{~mm}$, Power: -3.00 Diopter) were used [24]. The properties of these materials are described in Table 1. 
Table 1. Properties of contact lens materials evaluated in the study.

\begin{tabular}{lll}
\hline \multicolumn{1}{c}{ Proprietary name } & ACUVUE® 2 & ACUVUE® OASYS \\
$\begin{array}{l}\text { United States Adopted Name } \\
(\text { USAN) }\end{array}$ & etafilcon A & senofilcon A \\
\hline Manufacturer & $\begin{array}{l}\text { Johnson \& } \\
\text { Johnson }\end{array}$ & Johnson \& Johnson \\
\hline Water content (\%) & 58 & 38 \\
\hline Oxygen Permeability (Dk) & 21 & 103 \\
\hline Centre thickness (mm) - 3.00 Ds & 0.08 & 0.07 \\
\hline $\begin{array}{l}\text { Oxygen Transmissibility (Dk/t) at } \\
35^{\circ} \mathrm{C}\end{array}$ & 25 & 147 \\
\hline FDA group & IV & I \\
\hline $\begin{array}{l}\text { Surface treatment } \\
\text { None }\end{array}$ & $\begin{array}{l}\text { No surface treatment. Internal wetting agent } \\
\text { (PVP) that also coats the surface }\end{array}$ \\
\hline HEMA + MA & $\begin{array}{l}\text { mPDMS + DMA + HEMA + siloxane } \\
\text { macromer + PVP + TEGDMA }\end{array}$ \\
\hline
\end{tabular}

mPDMS, (monofunctional polydimethylsiloxane); DMA, (N,N-dimethylacrylamide); HEMA, (2-hydroxyethyl methacrylate); PVP, (polyvinyl pyrrolidone); TEGDMA (tetraethyleneglycol dimethacrylate); MA, (methacrylic acid).

\subsection{Bacterial Strains}

As the majority of the causative microorganisms for contact lens related microbial adverse events are Gram negative Pseudomonas aeruginosa and Gram positive Staphylococcus aureus [1,5], selected strains of these were used. Table 2 details the bacterial strains used in this study [19,25-28].

Table 2. Details of bacteria used in the study.

\begin{tabular}{cc}
\hline S. aureus strains & Isolation site \\
\hline S. aureus 31 [26] & CLPU - contact lens \\
\hline S. aureus $38[26]$ & MK \\
\hline P. aeruginosa strains & Isolation site \\
\hline P. aeruginosa $6294[25]$ & MK \\
\hline P. aeruginosa ATCC 9027 [27] & Otic infection \\
\hline P. aeruginosa GSU3 [19,28] & Human Corneal Ulcer
\end{tabular}

\subsection{Assay Media}

Four different types of bacterial suspension media, phosphate buffered saline $\mathrm{pH} 7.4$ (PBS; NaCl $8 \mathrm{~g} \mathrm{~L}^{-1}, \mathrm{KCl} 0.2 \mathrm{~g} \mathrm{~L}^{-1}, \mathrm{Na}_{2} \mathrm{HPO}_{4} 1.15 \mathrm{~g} \mathrm{~L}^{-1}, \mathrm{KH}_{2} \mathrm{PO}_{4} 0.2 \mathrm{~g} \mathrm{~L}^{-1}$ ), tryptone soy broth (TSB; Oxoid, Basingstoke, UK), TSB diluted 10X in sterile PBS (1/10 TSB), or 1/10 TSB containing glucose $(0.25 \% \mathrm{w} / \mathrm{v})(\mathrm{TSBG})$ were used. PBS acted as a nutritionally inert media and TSB as a highly nutritious media. 


\subsection{Incubation Period}

Contact lenses were incubated for two hours and 18 hours with the bacterial suspensions.

\subsection{Inoculum Size}

$1 \times 10^{3} \mathrm{CFU} \mathrm{mL}^{-1}, 1 \times 10^{6} \mathrm{CFU} \mathrm{mL}^{-1}$ and $1 \times 10^{10} \mathrm{CFU} \mathrm{mL}^{-1}$ are the three inoculum sizes used in this study.

\subsection{Adhesion Conditions}

Stock cultures were stored in $30 \%$ glycerol at $-80{ }^{\circ} \mathrm{C}$. Bacteria were grown overnight in TSB at $37{ }^{\circ} \mathrm{C}$ with aeration. The harvested bacterial cells were centrifuged for 10 mins at 3,000 rpm and the cells washed three times with PBS. All the bacteria were then resuspended in one of the four media to an $\mathrm{OD}_{660 \mathrm{~nm}}$ of $1.0\left(1 \times 10^{9} \mathrm{CFU} \mathrm{mL}^{-1}\right)$. The bacterial cell suspensions were then diluted to $1 \times 10^{6}$ and

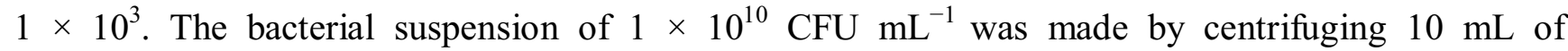
$1 \times 10^{9} \mathrm{CFU} \mathrm{mL} \mathrm{mL}^{-1}$ and resuspending it in $1 \mathrm{~mL}$ respective media. Contact lenses were washed three times in PBS and transferred to $1 \mathrm{~mL}$ of bacterial suspensions in wells of 24-well tissue culture plates (CELESTAR ${ }^{\circledR}$, Greiner bio-one, Frickenhausen, Germany), concave side up. To allow adhesion of bacterial cells, lenses were incubated for two hours or 18 hours at $37{ }^{\circ} \mathrm{C}$ with shaking (120 rpm). Lenses were aseptically removed from the suspension and washed three times with $1 \mathrm{~mL} P B S$ in a 24-well plate by shaking at $120 \mathrm{rpm}$ for 30 seconds to remove non-adherent cells. Following washing, contact lenses were stirred rapidly in $2 \mathrm{~mL}$ of PBS containing a small magnetic stirring bar. Following $\log _{10}$ serial dilutions in PBS, $3 \times 50 \mu \mathrm{L}$ of each dilution were plated on a nutrient agar (NA; Oxoid, Basingstoke, UK). After 24 hours incubation at $37{ }^{\circ} \mathrm{C}$, the viable bacteria were enumerated as $\mathrm{CFU} / \mathrm{lens} \mathrm{mm}^{2}$. The inoculum sizes were retrospectively counted by plating and overnight incubation on nutrient agar. Results are expressed as the numbers of adherent viable bacteria from three independent experiments with three samples evaluated each time.

\subsection{Statistics}

The adhesion data were $\log _{10}(\mathrm{x}+1)$ transformed prior to data analysis where $\mathrm{x}$ is the number of adherent bacterial colonies $\mathrm{mm}^{-2}$. All data were analyzed using Statistical Package for Social Science for Windows version 21.0 (SPSS, Inc, Chicago, IL). Interactions between different factors influencing bacterial adhesion to contact lenses such as bacterial strain type, assay media, incubation time and inoculum size were investigated in a nested model of all the variables. Based on this estimation, by factoring all the variables, the estimated mean was calculated which is adjusted for the other variables in the model. To evaluate and compare the influence of tested assay conditions on bacterial adhesion, partial Eta squared was estimated. Bacterial adhesion and contact lens parameters were analyzed using independent two sample $t$ test. Differences between the groups were analyzed using a linear mixed model ANOVA, which adjusts for the correlation due to repeated observations. Post hoc multiple comparisons were done using Bonferroni correction. Statistical significance was set at 5\%. 


\section{Results and Discussion}

Figures 1 and 2 show the adhesion of $P$. aeruginosa and $S$. aureus respectively when incubated in the four different media and at three different bacterial concentrations over time. Analysis of strain differences within a genera/species found that only $P$. aeruginosa ATCC 9027 showed higher adhesion to etafilcon A than senofilcon A $(p<0.01)$ and not for any other bacterial type. $P$. aeruginosa adhered at higher number compared to $S$. aureus $(p<0.01)$.

For each bacterial type and strain there was a significant increase in adhesion from 2 to 18 hours $(p<0.01)$ when incubated with $1 \times 10^{3} \mathrm{CFU} \mathrm{mL}^{-1}$ or $1 \times 10^{6} \mathrm{CFU} \mathrm{mL}^{-1}$ bacterial suspension. For $P$. aeruginosa strains, adhesion to the contact lenses increased as the initial inoculum increased $(p<0.01)$. However, for strains of $S$. aureus adhesion reached a maximum when $1 \times 10^{6} \mathrm{CFU} \mathrm{mL}^{-1}$ bacterial cells were incubated with lenses; addition of bacteria at $1 \times 10^{10} \mathrm{CFU} \mathrm{mL}^{-1}$ did not increase adhesion. The differences between the number of bacterial cells recovered from the washed solutions of the contact lenses incubated with different concentrations of bacteria was less than $0.3 \log$.

When comparing the effect of different media on adhesion, there were differences between the bacterial genera/species. For $P$. aeruginosa, adhesion was significantly lower $(p<0.01)$ when

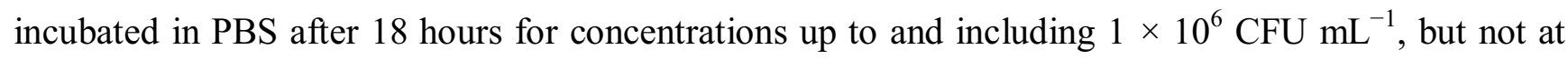
$1 \times 10^{10} \mathrm{CFU} \mathrm{mL} \mathrm{mL}^{-1}$. At $1 \times 10^{3} \mathrm{CFU} \mathrm{mL}^{-1}$ adhesion of $P$. aeruginosa was significantly higher when incubated with TSB $(p<0.01)$ compared to all other media, but this difference tended to lose significance at higher bacterial concentrations. For $S$. aureus, adhesion was significantly lower in PBS $(p<0.01)$ than all other media at all bacterial concentrations, at all time points and on both contact lens types. When $1 \times 10^{6}$ or $1 \times 10^{10} \mathrm{CFU} \mathrm{mL}^{-1}$ of $S$. aureus was used, there was a reduction in bacterial numbers adhered to lenses when incubated in PBS after $18 \mathrm{~h}$ adhesion compared to 2 hours adhesion; this was not the case with other media.

Figure 1. Adhesion of $P$. aeruginosa to contact lenses under different conditions ( $\mathrm{E}=$ etafilcon A lenses; $\mathrm{S}=$ senofilcon A lenses).

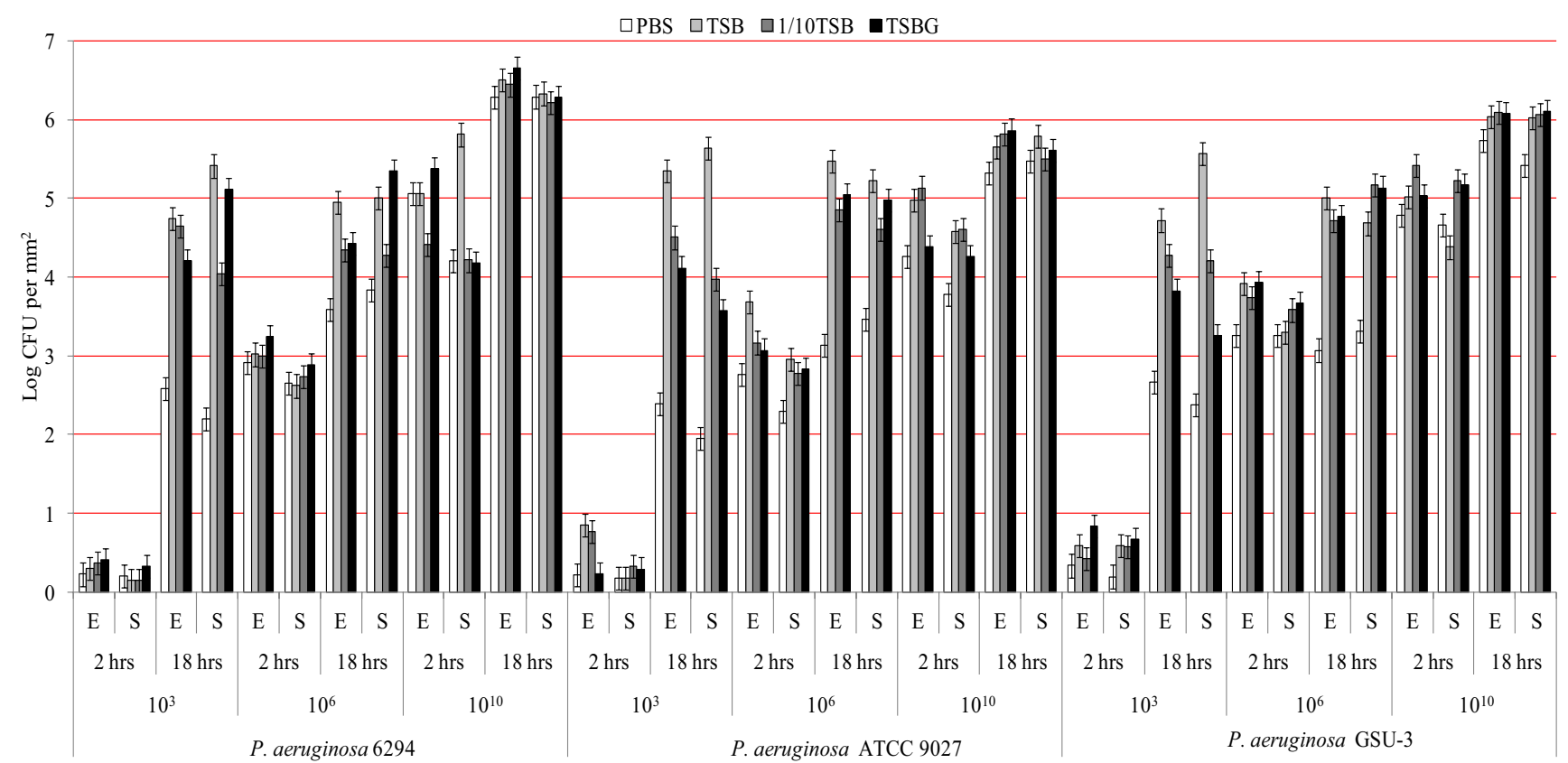


Figure 2. Adhesion of S. aureus to contact lenses under different conditions. ( $\mathrm{E}=$ etafilcon A lenses; $\mathrm{S}=$ senofilcon A lenses).

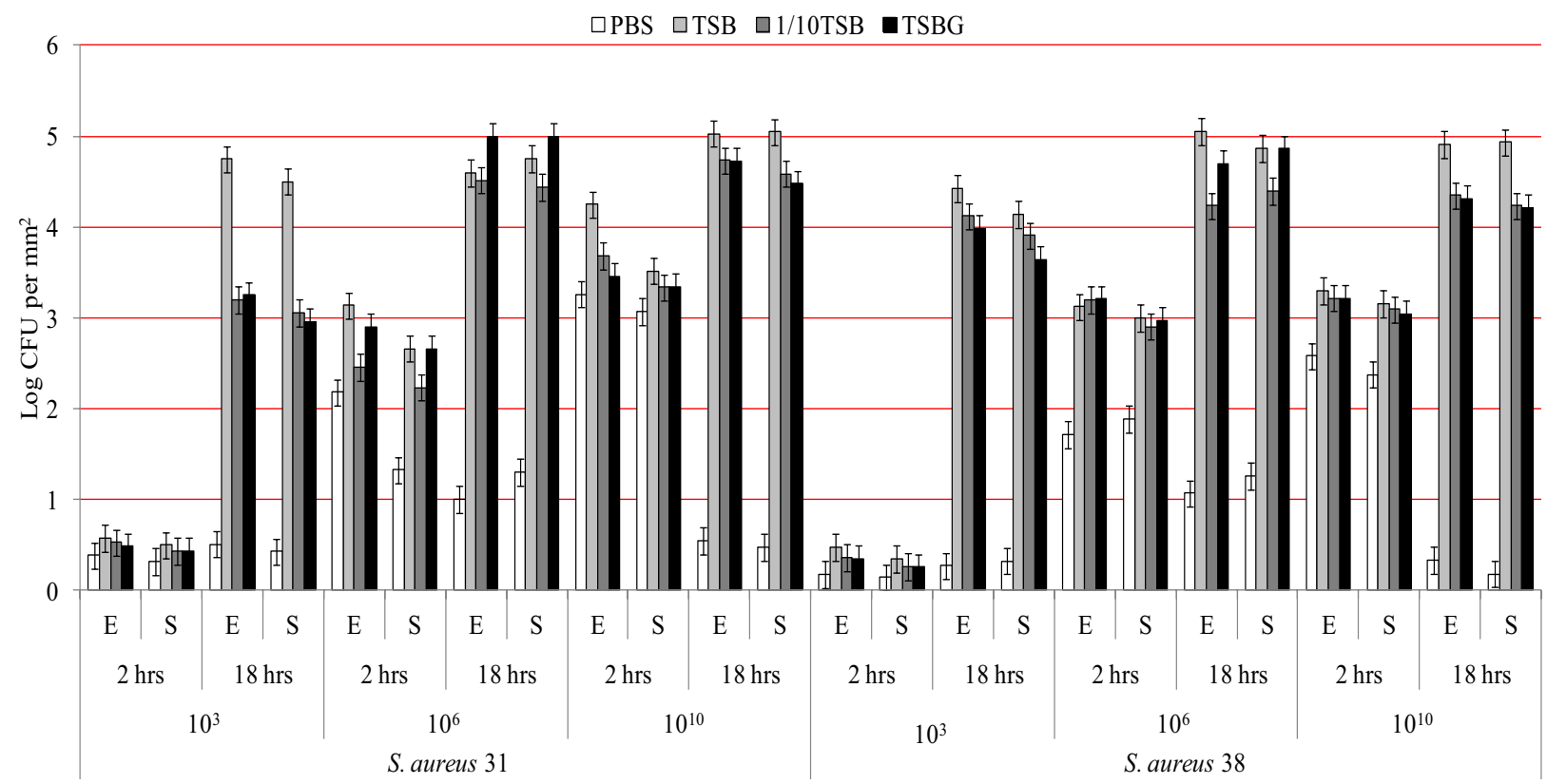

After adjusting for effects of incubation time, inoculum size and lens material, incubation with PBS showed significantly $(p<0.01)$ less adhesion for all the bacteria studied. There were no significant differences in bacterial adhesion $(p>0.05)$ when incubated with 1/10 TSB or TSBG. Incubation in the nutritionally rich TSB was often associated with higher adhesion (Figures 1 and 2) compared to other media especially after 18 hours.

Table 3 shows the estimated degree of association between bacterial adhesion and influencing assay conditions. Higher partial Eta squared value implies higher influence over bacterial adhesion. Variation in S. aureus strains did not influence bacterial adhesion (partial Eta squatted $=0.00$; $p=0.41)$. Rest all the factors including various P. aeruginosa strains, lens types, assay media, incubation period and inoculum size had significant influence $(p<0.05)$ on P. aeruginosa and S. aureus adhesion.

Table 3. Effect size of factors that influence bacterial adhesion.

\begin{tabular}{|l|c|c|}
\hline \multirow{2}{*}{$\begin{array}{c}\text { Influencing factor for } \\
\text { bacterial adhesion }\end{array}$} & \multicolumn{2}{|c|}{ Partial Eta squared } \\
\cline { 2 - 3 } Inoculum size & $\boldsymbol{P}$ aeruginosa & S. aureus \\
\hline Incubation period & 0.75 & 0.43 \\
\hline Assay media & 0.64 & 0.37 \\
\hline Type of lens & 0.19 & 0.54 \\
\hline Bacterial strains & 0.01 & 0.01 \\
\hline
\end{tabular}

In this study, adhesion of $P$. aeruginosa or $S$. aureus strains to contact lenses was assessed under several assay conditions. In most cases there was no significant difference in adhesion to hydrogel etafilcon A or silicone hydrogel senofilcon A lenses, which is consistent to some earlier studies [19]. However, this result was somewhat different to studies showing higher $P$. aeruginosa and $S$. aureus 
adhesion to silicone hydrogel contact lenses compared to hydrogel lenses [10,15,29]. Senofilcon A lenses have been shown to result in lower bacterial adhesion compared to other silicone hydrogels such as balafilcon A or lotrafilcon B used in previous studies [30].

Different strains of $P$. aeruginosa or $S$. aureus did not have significantly different adhesion to contact lenses. Previous studies have shown considerable variation in adhesion between different strains of $P$. aeruginosa or $S$. aureus, ranging up to $2.00 \times 10^{5} \mathrm{CFU} \mathrm{mm}^{-2}$ and $1.23 \times 10^{5} \mathrm{CFU} \mathrm{mm}^{-2}$ respectively [19,31-33]. Thus it is important to use the same strains across studies for meaningful comparisons to be made. Other strains can be incorporated as well to test for strain differences.

$P$. aeruginosa adhered at higher levels than $S$. aureus and this is in agreement with the previous reports [19,34]. However, the reason is not known in any great detail. It is known that cell surface appendages such as flagella and pili aid in the adhesion of $P$. aeruginosa [35] as does the relatively hydrophobic nature of some strains of $P$. aeruginosa compared to $S$. aureus [36]. This finding has been hypothesized to be a reason for the finding that $P$. aeruginosa is a predominant causative agent in contact lens induced-MK.

Previous studies have elucidated that the initial bacterial adhesion to contact lenses increases with time, peaked at 3 to 18 hours of incubation and then remained steady, suggesting the end point of primary adhesion [22,31,37]. Bacterial adhesion during two phases of the process, two hours and 18 hours exposure of contact lenses to bacterial suspension were determined in this study. The viable bacterial numbers after 18 hours adhesion were generally higher compared with after 2 hours, an observation that agrees with some previous studies [22,38]. Combining our results with Tran et al. [35] showing linear kinetics of bacterial adhesion up to 70 minutes and Randler et al. [22] investigating up to 72 hours but having incremental adhesion only up to 24 hours, illustrates that adhesion to contact lenses increases in a time dependant manner up to 18-24 hours of incubation and then viability is reduced. Perhaps, the reduction in viability is due to the bacteria entering a biofilm mode of growth, which is known to result in lower viability of cells $[39,40]$ or due to biofilm dispersal that can occur when the environment nutrients are not favorable for bacteria. In contrast, Stapleton et al. [41] and Andrews et al. [37] reported a plateau in adhesion that was reached after 45 minutes and four hours incubation respectively, with the adhesion that remained at those levels for more than 18 hours. These findings illustrates that investigators need to select incubation period of a bacterial adhesion carefully, depending upon study hypothesis being tested.

Bacterial incubation in the nutritionally rich media TSB resulted in the highest adhesion of both bacterial types. PBS, being nutritionally inert, resulted in apparent death or the more fastidious $S$. aureus strains used in the current study, and so PBS is not recommended as a media for adhesion experiments. This fact was supported by a test showing 18 hours incubation of $1 \times 10^{3} \mathrm{CFU} \mathrm{mL}^{-1}$, $1 \times 10^{6} \mathrm{CFU} \mathrm{mL}^{-1}$ and $1 \times 10^{10} \mathrm{CFU} \mathrm{mL}^{-1}$ significantly $(p<0.001)$ reduced mean $S$. aureus viability to $2.13 \times 10^{2} \mathrm{CFU} \mathrm{mL}{ }^{-1}, 2.55 \times 10^{3} \mathrm{CFU} \mathrm{mL}^{-1}$ and $9.13 \times 10^{4} \mathrm{CFU} \mathrm{mL}^{-1}$ in $\mathrm{PBS}$ (data not shown). This study demonstrates that diluted TSB can function as an adequate media for adhesion experiments. Since there was no significant difference in bacterial adhesion with $1 / 10$ TSB and TSBG, addition of glucose is not recommended.

Since it is difficult to quantify exposure of contact lenses to microorganisms during wear, a wide range of numbers were selected for testing; $1 \times 10^{3} \mathrm{CFU} \mathrm{\textrm {mL } ^ { - 1 }}$ represented a low inoculum size, $1 \times 10^{6} \mathrm{CFU} \mathrm{mL} \mathrm{mL}^{-1}$ a medium inoculum size and $1 \times 10^{10} \mathrm{CFU} \mathrm{mL}^{-1}$ represented very high inoculum 
size. $1 \times 10^{10} \mathrm{CFU} \mathrm{mL} \mathrm{m}^{-1}$ was usually associated with highest adhesion, especially when incubated for 2 hours. Previous studies have also used higher inoculum sizes when incubation times were short [41-43] and a lower inoculum size when incubated for longer [20,21]. Contact lenses will rarely be exposed to such high numbers of bacteria such as $1 \times 10^{10} \mathrm{CFU} \mathrm{mL} \mathrm{m}^{-1}$ during contact lens wear or even in lens cases. The range of bacterial numbers isolated from contact storage lens storage cases has been reported to be $1.24 \times 10^{4} \mathrm{CFU} /$ case to $6.32 \times 10^{4} \mathrm{CFU} /$ case [44-49]. Therefore, exposing contact lenses to this level of bacteria may be unrealistic. The data from the current experiments suggest that an inoculum size of $1 \times 10^{6} \mathrm{CFU} \mathrm{mL}^{-1}$ may offer a more realistic level of bacteria to expose contact lenses to, and results in medium to high levels of bacterial adhesion.

Inoculum size was the greatest influencing factor for $P$. aeruginosa adhesion, followed by incubation period and assay media. Interestingly, nutritionally variable assay media was the greatest influencing factor determining $S$. aureus adhesion, confirming that $S$. aureus is sensitive to the nutritional content. Incubation period and inoculum size were the other major influencing factors. Lens types and bacterial strains had a minor influence.

A limitation of this study is that bacterial adhesion to contact lens was not evaluated at frequent time intervals, which might have provided better understanding regarding kinetics of bacterial adhesion. Bacterial adhesion after longer incubation period such as 18 hours is complex procedure because of the bacteria are more likely to be replicating during this time, especially under nutrient enhanced conditions, probably combinations of initial biofilm formation and continued initial adhesion of daughter cells. This study has evaluated adhesion at a fixed stirring rate $(120 \mathrm{rpm})$, thus altering the rate will undoubtedly implicate the rate of bacterial arrival to lenses. Since, it is difficult to reproduce in vivo blinking motion onto contact lens surfaces in vitro, we would recommend using a constant shaking rate (such as used in this study; $120 \mathrm{rpm}$ ) for a particular study design. In addition, total microbial load cannot be investigated by this type of assay. However, viable plate count is a vital method to evaluate reproducible microbial count, essential for development of infection and inflammation especially at the ocular environment [3]. Based on the results obtained in this study we suggest 18 hours incubation of $10^{6} \mathrm{CFU} \mathrm{mL}^{-1}$ S. aureus or P. aeruginosa in $1 / 10 \mathrm{TSB}$ or PBS respectively to study the attachment of bacteria to contact lenses. The advantages of this recommended assay also include that better results could be achieved with the use of basic laboratory apparatuses and does not require expensive machines such confocal or optical microscope and microtitre plate reader. The bacterial adhesion assay used in this study suits best to investigate increase or decrease in viable count such as used in antimicrobial research.

It is important to carefully select assay conditions depending on the study purpose. Adhesion of P. aeruginosa to contact lenses ranged from $1.38 \mathrm{CFU} \mathrm{mm}^{-2}$ to $4.57 \times 10^{6} \mathrm{CFU} \mathrm{mm}^{-2}$ and $S$. aureus

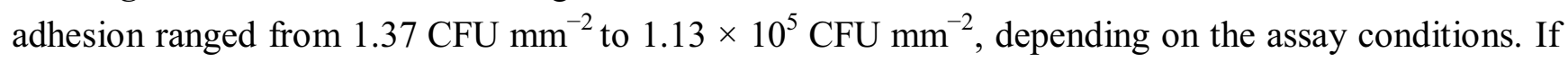
experiments are designed to investigate effect of materials on bacterial adhesion, or whether antimicrobial lenses can reduce adhesion, it is important that assay conditions are chosen that allow adhesion to control lenses at a medium range so that increases or decreases in adhesion can be measured. A set of such assay conditions is given in Table 4 that have provided moderate adhesion of between $1 \times 10^{3} \mathrm{CFU} \mathrm{m^{-2 }}$ to $1 \times 10^{5} \mathrm{CFU} \mathrm{m^{-2 }}$ for $P$. aeruginosa and $1 \times 10^{3} \mathrm{CFU} \mathrm{m^{-2 }}$ to $1 \times 10^{4.5} \mathrm{CFU} \mathrm{mm}{ }^{-2}$ for $S$. aureus for both contact lens types. 
I

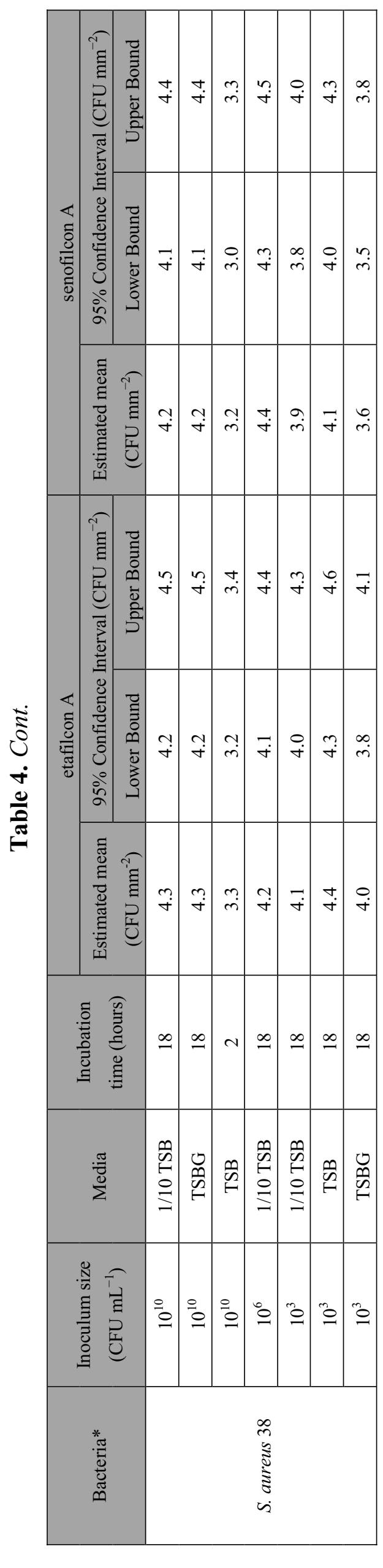


In conclusion, this study has determined that different strains of $P$. aeruginosa or $S$. aureus do not adhere very differently to contact lenses. Adhesion is more affected by the environment and numbers of bacteria initially applied to lenses. At least for etafilcon A and senofilcon A lenses, adhesion was not affected by lens polymer type. There are varieties of ingredients used to evaluate bacterial adhesion and investigators are required to select a set of bacterial assay depending on the study hypothesis. The proposed conditions that give intermediate levels of bacterial adhesion to contact lenses could be used for subsequent evaluation of bacterial adhesion to lenses or antibacterial efficacy of contact lenses.

\section{Conflict of Interest}

This work is original, has not been published and is not being considered for publication elsewhere. There are no conflicts of interest for any of the authors that could have influenced the results of this work. The first author is supported by the University International Postgraduate Award (UIPA) UNSW, and top-up scholarships from the OVRF Maki Shiobara Scholarship and Brien Holden Vision Institute.

\section{References}

1. Green, M.; Apel, A.; Stapleton, F. Risk factors and causative organisms in microbial keratitis. Cornea 2008, 27, 22-27.

2. Holden, B.A.; La Hood, D.; Grant, T.; Newton-Howes, J.; Baleriola-Lucas, C.; Willcox, M.D.; Sweeney, D.F. Gram-negative bacteria can induce contact lens related acute red eye (CLARE) responses. CLAO J. 1996, 22, 47-52.

3. Wu, P.; Stapleton, F.; Willcox, M.D. The causes of and cures for contact lens-induced peripheral ulcer. Eye Contact Lens 2003, 29, S63-S66.

4. Willcox, M.; Sharma, S.; Naduvilath, T.J.; Sankaridurg, P.R.; Gopinathan, U.; Holden, B.A. External ocular surface and lens microbiota in contact lens wearers with corneal infiltrates during extended wear of hydrogel lenses. Eye Contact Lens 2011, 37, 90-95.

5. Otri, A.M.; Fares, U.; Al-Aqaba, M.A.; Miri, A.; Faraj, L.A.; Said, D.G.; Maharajan, S.; Dua, H.S. Profile of sight-threatening infectious keratitis: A prospective study. Acta ophthalmologica 2012.

6. Tuli, S.S.; Iyer, S.A.; Driebe, W.T., Jr. Fungal keratitis and contact lenses: An old enemy unrecognized or a new nemesis on the block? Eye Contact Lens 2007, 33, 415-417.

7. Yoder, J.S.; Verani, J.; Heidman, N.; Hoppe-Bauer, J.; Alfonso, E.C.; Miller, D.; Jones, D.B.; Bruckner, D.; Langston, R.; Jeng, B.H.; et al. Acanthamoeba keratitis: the persistence of cases following a multistate outbreak. Ophthalmic Epidemiol. 2012, 19, 221-225.

8. Keay, L.; Edwards, K.; Naduvilath, T.; Forde, K.; Stapleton, F. Factors affecting the morbidity of contact lens-related microbial keratitis: A population study. Invest. Ophthalmol. Vis. Sci. 2006, 47, 4302-4308.

9. Dutta, D.; Cole, N.; Willcox, M. Factors influencing bacterial adhesion to contact lenses. Mol. Vis. 2012, 18, 14-21. 
10. Giraldez, M.J.; Resua, C.G.; Lira, M.; Oliveira, M.E.; Magarinos, B.; Toranzo, A.E.; Yebra-Pimentel, E. Contact lens hydrophobicity and roughness effects on bacterial adhesion. Optom. Vis. Sci. 2010, 87, E426-E431.

11. Willcox, M.D.P.; Hume, E.B.H.; Aliwarga, Y.; Kumar, N.; Cole, N. A novel cationic-peptide coating for the prevention of microbial colonization on contact lenses. J. Appl. Microbiol. 2008, 105, 1817-1825.

12. Garcia-Saenz, M.C.; Arias-Puente, A.; Fresnadillo-Martinez, M.J.; Paredes-Garcia, B. Adherence of two strains of Staphylococcus epidermidis to contact lenses. Cornea 2002, 21, 511-515.

13. Vermeltfoort, P.B.; Rustema-Abbing, M.; de Vries, J.; Bruinsma, G.M.; Busscher, H.J.; van der Linden, M.L.; Hooymans, J.M.; van der Mei, H.C. Influence of day and night wear on surface properties of silicone hydrogel contact lenses and bacterial adhesion. Cornea 2006, 25, 516-523.

14. Mathews, S.M.; Spallholz, J.E.; Grimson, M.J.; Dubielzig, R.R.; Gray, T.; Reid, T.W. Prevention of bacterial colonization of contact lenses with covalently attached selenium and effects on the rabbit cornea. Cornea 2006, 25, 806-814.

15. Kodjikian, L.; Casoli-Bergeron, E.; Malet, F.; Janin-Manificat, H.; Freney, J.; Burillon, C.; Colin, J.; Steghens, J.P. Bacterial adhesion to conventional hydrogel and new silicone-hydrogel contact lens materials. Graefes Arch. Clin. Exp. Ophthalmol. 2008, 246, 267-273.

16. Williams, T.J.; Schneider, R.P.; Willcox, M.D. The effect of protein-coated contact lenses on the adhesion and viability of gram negative bacteria. Curr. Eye Res. 2003, 27, 227-235.

17. George, M.; Ahearn, D.; Pierce, G.; Gabriel, M. Interactions of Pseudomonas aeruginosa and Staphylococcus epidermidis in adhesion to a hydrogel. Eye Contact Lens 2003, 29, S105-S109; Discussion S115-S118, S192-S194.

18. Dutta, D.; Cole, N.; Kumar, N.; Willcox, M.D. Broad spectrum antimicrobial activity of melimine covalently bound to contact lenses. Invest. Ophthalmol. Vis. Sci 2013, 54, 175-182.

19. Borazjani, R. Relative primary adhesion of Pseudomonas aeruginosa, Serratia marcescens and Staphylococcus aureus to HEMA-type contact lenses and an extended wear silicone hydrogel contact lens of high oxygen permeability. Cont. Lens Anterior Eye 2004, 27, 3-8.

20. Bandara, B.M.K.; Sankaridurg, P.R.; Willcox, M.D.P. Non-steroidal anti inflammatory agents decrease bacterial colonisation of contact lenses and prevent adhesion to human corneal epithelial cells. Curr. Eye Res. 2004, 29, 245-251.

21. Willcox, M.D.; Hume, E.B.; Vijay, AK.; Petcavich, R. Ability of silver-impregnated contact lenses to control microbial growth colonisation. J. Optom. 2010, 3, 143-148.

22. Randler, C.; Matthes, R.; McBain, A.; Giese, B.; Fraunholz, M.; Sietmann, R.; Kohlmann, T.; Hubner, N.; Kramer, A. A three-phase in-vitro system for studying Pseudomonas aeruginosa adhesion and biofilm formation upon hydrogel contact lenses. BMC Microbiol. 2010, 9, 12.

23. McLaughlin-Borlace, L.; Stapleton, F.; Matheson, M.; Dart, J.K. Bacterial biofilm on contact lenses and lens storage cases in wearers with microbial keratitis. J. Appl. Microbiol. 1998, 84, 827-838.

24. Efron, N.; Morgan, P.B.; Woods, C.A. Survey of contact lens prescribing to infants, children, and teenagers. Optom. Vis. Sci. 2011, 88, 461-468. 
25. Fleiszig, S.M.J.; WienerKronish, J.P.; Miyazaki, H.; Vallas, V.; Mostov, K.E.; Kanada, D.; Sawa, T.; Yen, T.S.B.; Frank, D.W. Pseudomonas aeruginosa-mediated cytotoxicity and invasion correlate with distinct genotypes at the loci encoding exoenzyme S. Infec. Immunity 1997, 65, 579-586.

26. Schubert, T.L.; Hume, E.B.; Willcox, M.D. Staphylococcus aureus ocular isolates from symptomatic adverse events: antibiotic resistance and similarity of bacteria causing adverse events. Clin. Exp. Optom. 2008, 91, 148-155.

27. Lakkis, C.; Fleiszig, S.M. Resistance of Pseudomonas aeruginosa isolates to hydrogel contact lens disinfection correlates with cytotoxic activity. J. Clin. Microbiol. 2001, 39, 1477-1486.

28. Parment, P.A.; Gabriel, M.; Bruse, G.W.; Stegall, S.; Ahearn, D.G. Adherence of Serratia marcescens, Serratia liquefaciens, Pseudomonas aeruginosa and Staphylococcus epidermidis to blood transfusion bags (CPD-SAGMAN sets). Scand. J. Infec. Dis. 1993, 25, 721-724.

29. Henriques, M.; Sousa, C.; Lira, M.; Elisabete, M.; Oliveira, R.; Azeredo, J. Adhesion of Pseudomonas aeruginosa and Staphylococcus epidermidis to silicone-hydrogel contact lenses. Optom. Vis. Sci 2005, 82, 446-450.

30. Subbaraman, L.N.; Borazjani, R.; Zhu, H.; Zhao, Z.; Jones, L.; Willcox, M.D. Influence of protein deposition on bacterial adhesion to contact lenses. Optom. Vis. Sci. 2011, 88, 959-966.

31. Miller, M.J.; Ahearn, D.G. Adherence of Pseudomonas aeruginosa to hydrophilic contact lenses and other substrata. J. Clin. Microbiol. 1987, 25, 1392-1397.

32. Klotz, S.A.; Butrus, S.I.; Misra, R.P.; Osato, M.S. The contribution of bacterial surface hydrophobicity to the process of adherence of Pseudomonas aeruginosa to hydrophilic contact lenses. Curr. Eye Res. 1989, 8, 195-202.

33. Vijay, A.K.; Zhu, H.; Ozkan, J.; Wu, D.; Masoudi, S.; Bandara, R.; Borazjani, R.N.; Willcox, M.D. Bacterial adhesion to unworn and worn silicone hydrogel lenses. Optom. Vis. Sci. 2012, 89, 1095-1106.

34. Zhang, S.; Borazjani, R.N.; Salamone, J.C.; Ahearn, D.G.; Crow, S.A., Jr.; Pierce, G.E. In vitro deposition of lysozyme on etafilcon A and balafilcon A hydrogel contact lenses: Effects on adhesion and survival of Pseudomonas aeruginosa and Staphylococcus aureus. Cont. Lens Anterior Eye 2005, 28, 113-119.

35. Tran, V.B.; Fleiszig, S.M.; Evans, D.J.; Radke, C.J. Dynamics of flagellum- and pilus-mediated association of Pseudomonas aeruginosa with contact lens surfaces. Appl. Environ. Microbiol. 2011, 77, 3644-3652.

36. Bruinsma, G.M.; van der Mei, H.C.; Busscher, H.J. Bacterial adhesion to surface hydrophilic and hydrophobic contact lenses. Biomaterials 2001, 22, 3217-3224.

37. Andrews, C.S.; Denyer, S.P.; Hall, B.; Hanlon, G.W.; Lloyd, A.W. A comparison of the use of an ATP-based bioluminescent assay and image analysis for the assessment of bacterial adhesion to standard HEMA and biomimetic soft contact lenses. Biomaterials 2001, 22, 3225-3233.

38. Szczotka-Flynn, L.B.; Imamura, Y.; Chandra, J.; Yu, C.; Mukherjee, P.K.; Pearlman, E.; Ghannoum, M.A. Increased resistance of contact lens-related bacterial biofilms to antimicrobial activity of soft contact lens care solutions. Cornea 2009, 28, 918-926.

39. Donlan, R.M.; Costerton, J.W. Biofilms: Survival mechanisms of clinically relevant microorganisms. Clin. Microbiol. Rev. 2002, 15, 167-193. 
40. Evans, D.J.; Allison, D.G.; Brown, M.R.; Gilbert, P. Effect of growth-rate on resistance of gram-negative biofilms to cetrimide. J. Antimicrob. Chemother. 1990, 26, 473-478.

41. Stapleton, F.; Dart, J.; Matheson, M.; Woodward, E. Bacterial adherence and glycocalyx formation on unworn hydrogel lenses. J. Brit. Contact Lens Assoc. 1993, 16, 113-116.

42. Williams, T.J.; Willcox, M.D.; Schneider, R.P. Interactions of bacteria with contact lenses: The effect of soluble protein and carbohydrate on bacterial adhesion to contact lenses. Optom. Vis. Sci. 1998, 75, 266-271.

43. Miller, M.J.; Wilson, L.A.; Ahearn, D.G. Effects of protein, mucin, and human tears on adherence of Pseudomonas aeruginosa to hydrophilic contact lenses. J. Clin. Microbiol. 1988, 26, 513-517.

44. Willcox, M.D.; Carnt, N.; Diec, J.; Naduvilath, T.; Evans, V.; Stapleton, F.; Iskandar, S.; Harmis, N.; de la Jara, P.L.; Holden, B.A. Contact lens case contamination during daily wear of silicone hydrogels. Optom. Vis. Sci. 2010, 87, 456-464.

45. Dantam, J.; Zhu, H.; Willcox, M.; Ozkan, J.; Naduvilath, T.; Thomas, V.; Stapleton, F. In vivo assessment of antimicrobial efficacy of silver-impregnated contact lens storage cases. Invest. Ophthalmol. Vis. Sci. 2012, 53, 1641-1648.

46. Pens, C.J.; da Costa, M.; Fadanelli, C.; Caumo, K.; Rott, M. Acanthamoeba spp. and bacterial contamination in contact lens storage cases and the relationship to user profiles. Parasitol. Res. 2008, 103, 1241-1245.

47. Fleiszig, S.M.; Efron, N. Microbial flora in eyes of current and former contact lens wearers. J. Clin. Microbiol. 1992, 30, 1156-1161.

48. Donzis, P.B.; Mondino, B.J.; Weissman, B.A.; Bruckner, D.A. Microbial contamination of contact lens care systems. Am. J. Ophthalmol. 1987, 104, 325-333.

49. Wilson, L.A.; Sawant, A.D.; Simmons, R.B.; Ahearn, D.G. Microbial contamination of contact lens storage cases and solutions. Am. J. Ophthalmol. 1990, 110, 193-198.

(C) 2013 by the authors; licensee MDPI, Basel, Switzerland. This article is an open access article distributed under the terms and conditions of the Creative Commons Attribution license (http://creativecommons.org/licenses/by/3.0/). 